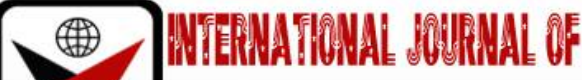

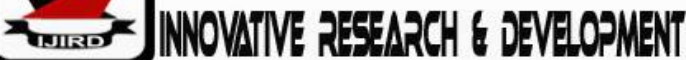

ISSN 2278 - 0211 (Online)

\section{The Influence of Transformational Leadership and Career Development on Employee Performance with Commitment of the Organization as a Mediation Variable in the Department of Health, Klungkung District, Indonesia}

\begin{tabular}{c} 
Kadek Body Kotama \\
Magister Management Program, Post Graduate, \\
University of Mahasaraswati, Denpasar, Indonesia \\
I Wayan Sujana \\
Magister Management Program, Post Graduate, \\
University of Mahasaraswati, Denpasar, Indonesia \\
Nengah Landra \\
Magister Management Program, Post Graduate, \\
University of Mahasaraswati, Denpasar, Indonesia \\
I Nengah Suardhika \\
Magister Management Program, Post Graduate, \\
University of Mahasaraswati, Denpasar, Indonesia \\
\hline
\end{tabular}

\begin{abstract}
:
The performance of the bureaucracy is often in the spotlight of the community so that it becomes a challenge for the bureaucracy, a spotlight on the performance of the bureaucracy due to the many problems it faces. Performance is an important thing that must be achieved by every agency including the Klungkung District Health Office, because performance is a reflection of the agency's ability to manage and allocate employees, therefore the performance of employees has a very important influence on the ongoing activities of the agency and affects the achievement process. agency goals. This study aims to determine the effect of transformational leadership and career development on employee performance with organizational commitment as a variable. This research is a survey research, with a total sample of 82 selected by total sampling. The results showed transformational leadership proven to have a positive and significant effect on organizational commitment. Career development has a positive and significant influence on organizational commitment. Transformational leadership proven to have a positive and significant effect on organizational commitments, organizational commitment has not been able to mediate on the indirect effect transformational leadership on employee performance. Career development has a positive and significant influence on employee performance, there is another side to organizational commitment has not been able to mediate the indirect effect career development on employee performance. Organizational commitment has a positive and significant influence on employee performance. It is recommended that management prioritize career development for employees who have completed higher education and have high performance in carrying out their duties
\end{abstract}

Keywords: Transformational Leadership, Career Development, Organizational Commitment, Employee Performance

\section{Introduction}

The performance of the bureaucracy is often in the spotlight of the community so that it becomes a challenge for the bureaucracy, the spotlight on the performance of the bureaucracy is due to the many problems faced by the government such as long bureaucracy, unprofessional employees, centralized work mechanisms, employee placement is not as needed, inadequate service makes institutional performance the government cannot be said to be good (Sedarmayanti, 2015). This performance is increasingly important and urgent as a result of the shift in the management paradigm of Government that starts from "government" to "governance" with the main objective of creating "good governance" and public satisfaction with public services (Widodo, 2013). To create "good governance" and public service satisfaction as a manifestation of good governance, Civil Servants (PNS) must be more competent in carrying out their duties and functions. The competence of civil servants is reflected in the perfection of work results, timeliness, ability to carry out work, ability to convey messages or work results (Winardi, 2015). 
In line with the policy direction of the decentralization program as mandated in Law Number 32 of 2004 concerning Regional Government, it has determined that the health sector is one of the mandatory affairs that must be carried out by districts / cities, the implementation of mandatory functions by regions as a manifestation of regional autonomy or authority in carrying out tasks. and obligations that must be borne by the district / city. The implementation of mandatory government affairs, guided by minimum service standards, is carried out gradually and determined by the government (Law Number 32 of 2004). / VII / 2008 concerning Minimum Service Standards in the Health Sector in districts / cities. Minimum Service Standards (SPM) are benchmarks for the performance of health services, which are mandatory regional affairs for which every citizen is entitled. Basic services are the function of the government in providing and managing the basic needs of the community to improve the welfare of the people (Ministry of Health, 2008). The annual target of SPM is a performance plan for activities carried out within a certain period of time, which requires input and process. The health program process in the form of individual service activities, community service activities, management activities and capacity building activities (Gani, 2014) Basic services are the function of the government in providing and managing the basic needs of the community to improve the welfare of the people (Ministry of Health, 2008). The annual target of SPM is a performance plan for activities carried out within a certain period of time, which requires input and process. The health program process in the form of individual service activities, community service activities, management activities and capacity building activities (Gani, 2014) Basic services are the function of the government in providing and managing the basic needs of the community to improve the welfare of the people (Ministry of Health, 2008). The SPM annual target is a performance plan for activities carried out within a certain period of time, which requires input and process. The health program process in the form of individual service activities, community service activities, management activities and capacity building activities (Gani, 2014)

The Health Office is one of the SKPDs within the Klungkung Regency government which is responsible for the field of health development. Details of the main duties of the official function as a technical agency. The Health Office is an agency engaged in public health services, where the success of the implementation of duties and responsibilities in the agency depends on the performance of the employees in the agency, the importance of the performance of employees at the Health Office greatly influences the implementation of the agency's goals, namely to improve services to the community (Klungkung District Health Office, 2018).

The minimum standard achievement which is the target for the performance of the health office employees in three years has never been achieved according to the target, namely $100 \%$, the highest achievement is 86.2 and the highest achievement is $48.8 \%$.Performance is an important thing that must be achieved by every agency including the Klungkung District Health Office, because performance is a reflection of the agency's ability to manage and allocate employees, therefore the performance of employees has a very important influence on the ongoing activities of the agency and affects the achievement process. agency goals. Sedarmayanthi (2015) states that performance is the result of work that can be obtained by workers, a management process or an organization as a whole, where the results of this work can be shown real evidence both in terms of quality and quantity.

One of the factors that can improve employee performance is the leadership factor. Employee performance will not be separated from the leadership role that exists in the organization. This is because leadership can lead to organizational goals, motivate behavior towards achieving these goals, and be able to define organizational culture (Griffin 2012). Leadership is an important factor of the company because in reality, leaders can influence employee morale and job satisfaction, security, quality of work life, and especially the level of achievement of an organization (Handoko, 2013). Transformational leadership shows the leader's ability to encourage followers with his vision, improve the skills and abilities of followers, pay attention to their interests by cultivating, training as needed. Transformational leadership has also been associated with outcomes such as innovation, quality improvement and performance. Leadership is the process of influencing the activities of individuals or groups to achieve goals in certain situations (Gibson, 2013). Research by Dewi (2018) shows that leadership has a positive and significant effect on employee performance. Septyan's (2016) research shows that transformational leadership has a positive and significant effect on employee performance. Different results were obtained by Cahyono (2016) who found that k Research by Dewi (2018) shows that leadership has a positive and significant effect on employee performance. Septyan's (2016) research shows that transformational leadership has a positive and significant effect on employee performance. Different results were obtained by Cahyono (2016) who found that k Research by Dewi (2018) shows that leadership has a positive and significant effect on employee performance. Septyan's (2016) research shows that transformational leadership has a positive and significant effect on employee performance. Different results were obtained by Cahyono (2016) who found that key transformational leadership has no effect on performance.

Employee career development is also an important factor in supporting employee performance. For the development of an organization, therefore, efforts are needed to improve the skills and professionalism of employees in providing attention and coaching which in turn are expected to develop employee careers (Perdana and Andriyani, 2019). The results of research from the State (2014) show that career development has an impact on improving employee performance. Rosmadi's research (2017) shows that career development has a significant effect on employee performance. Ramli's research (2017) found that career development can significantly improve employee performance which is supported by high employee organizational commitment.

Organizational commitment also affects employee performance. According to Luthans (2014) organizational commitment is a strong desire to remain as a member of the organization, certain beliefs, and acceptance of organizational values and goals, while according to Nikpour (2017) organizational commitment itself is an attitude shown by individuals with identification, involvement and loyalty. against the organization, as well as the desire to remain in the organization and are not willing to leave the organization under any circumstances. In other words, it is an attitude that reflects 
employee loyalty to the organization and a continuous process where members of the organization express their concern for the organization and its success, as well as continuous progress. Commitment has an important role, especially in a person's performance at work, this is due to a commitment that becomes a reference and encouragement that makes them more responsible for their obligations. However, in reality many organizations or companies do not pay attention to the commitment / loyalty of their employees, so that their performance is not optimal. Tanuwibowo's research (2017)shows that organizational commitment is positively related to employee performance. Septiani's (2018) research shows thatorganizational commitment matters significant to employee performance. Different results were obtained by Marsoit (2017) who found organizational commitment had no effect on employee performance and Sularso's research (2015) showed that organizational commitment could not improve employee performance.

Organizational commitment is also able to mediate the effect of transformational leadership on employee performance according to that research conducted by Suhana (2017) shows that relationship-oriented leadership behavior which includes building trust, providing inspiration, vision, encouraging creativity and emphasizing development has a positive effect on employee affective commitment. Meanwhile, task-oriented leadership behavior also affects employee affective commitment, although the level of influence is lower. Jose's research (2018) shows that the higher the transformational leadership, the higher the organizational commitment, and the higher the employee's performance (Vipraprastha, Sudja \& Yuesti, 2018); (Manggis, Yuesti \& Sapta, 2018).

Based on problems and Research Gap above, the author is interested in conducting research on the effect of transformational leadership and career development on employee performance with organizational commitment as a mediating variable in the Klungkung District Health Office.

\section{Literature Review}

A leader is someone who uses his authority and leadership to direct his subordinates to do some of his work to achieve organizational goals, while leadership is a way for a leader to influence the behavior of subordinates so that they are willing to work together and work productively to achieve organizational goals (Hasibuan, 2012). Transformational leadership seeks to bring individuals and teams to work beyond the status-quo. The transformational leader is a person who has the power to bring about change in team members and in the organization as a whole. According to him, transformational leadership can be used when needed to improve performance (O'Leary, 2012).

According to Bass, 2006 in Mutamimah (2013) supported by O'Leary's (2012) opinion, there are several dimensions of transformational leadership, namely Charismatic Leadership (Berkharisma), namely the leader has power and influence. Employees are raised, so they have a level of trust and confidence. Leaders awaken and delight their employees by making sure they can get something bigger with extra effort; Inspirational Motivation, namely transformational leaders always motivate and stimulate their subordinates by preparing meaningful and challenging jobs, shown enthusiasm and optimism. Leaders always communicate the vision, mission and expectations with the aim that subordinates have a high commitment to achieving goals; Intellectual Stimulation, namely the leader always stimulates his subordinates intellectually, so that they become innovative and creative in solving problems in new ways. In addition, leaders teach by seeing difficulties as problems that must be solved and providing rational problem solving; Individualized Consideration, namely the leader pays attention to individual employees, such as: the employee's need for achievement, providing salaries, giving advice to employees so that employees can grow and develop. With all of this the impact that arises is that employee performance is expected to increase, and with the increase in employee performance it is expected that organizational performance will also increase

Career development shows the development of an individual employee in the level of position or rank achieved during the employee's work or experience during his tenure in an organization. On the other hand, career can also show each individual with their role or status in the organization. Career development is aimed at seeing a person's career advancement from one level to another. This is in accordance with Handoko's statement (2012) where career development is personal improvements that a person makes to achieve a career plan. Prihansa (2016) argues that with career planning and development, clear benefits for employees are satisfaction, personal development, and a quality work life.

Career development is one of the factors organization that can affect performance, this is in accordance with the theory of Rivai and Sagala (2014) career development is a process of increasing individual work abilities achieved in order to achieve the desired career. The objective of all career development programs is to match the needs and goals of employees with the career opportunities available in the company today and in the future. The better the employee's career development, the higher the employee's performance in carrying out their duties.

Griffin (2012) argues that organizational commitment is an attitude that reflects the extent to which an individual knows and is bound to his organization. A highly committed individual will likely see himself or herself as a true member of the organization. Durkin (1999) in Zurnali (2014) states that nurses who have a strong normative commitment will stay with the organization because they feel that they have to live together (because they fell that they have to). Yatnikasari (2010) argues that the normative commitment of nurses is very dependent on the initial socialization and form of one's role from the experience of the organization. Nurses with high commitment tend to feel happy at work because they have to manifest what has become their belief in the organization. Nurses have high normative commitment. This cannot be separated from the role of hospital management in managing nurses well. Hospital management has instilled organizational commitment, which includes affective commitment, continuous commitment and especially in this case normative commitment to nurses during recruiting and in the form of training for new nurses or promotion to senior nurses so that the performance of nurses in the hospital is high and tends to be increased. 
Highly committed employees will have high performance and this is in line (Luthans, 2014) which suggests that employees with high organizational commitment have different attitudes than those with low commitment. High organizational commitment results in work performance, low levels of absenteeism, and low employee turnover. Highly committed employees will have high productivity, thus the first hypothesis in this study is that organizational commitment has an influence on performance.

The success of an organization or company is determined by a leader who leads the organization. A leader with transformational leadership has a vision for the future and is able to identify environmental changes and is able to transform these changes into the organization. Transformational leadership also provides inspiration and motivation in employees, so that it can create high organizational commitment. An employee who has a high commitment will have an identification with the organization, are seriously involved in the work and there is loyalty and positive affection for the organization. However, in reality the civil servants in the Klungkung District Health Office have a low affective commitment, it can be seen when there is supervision from their superiors, almost all civil servants work their best, however, when they are not supervised, the civil servants will work as they please. This shows that employees do not fully believe in the company and are willing to accept the company's values. Thus it can be concluded that if a leader has the ability to mobilize and empower employees, it can affect organizational commitment. This is in accordance with the results of research conducted by Kesuma (2018) showing thatTransformational leadership has a positive and significant effect on organizational commitment. Ahmad's research (2016) states that there is a positive influence of transformational leadership style with performance on organizational commitment as an intervening variable. This shows that the better the leadership style is applied, the higher the organizational commitment, which has an impact on improving its performance.

According to Zurnali (2014), one of the factors in the formation of work commitment is career development. Therefore, the company must make a career development system as best as possible. Its employees are still motivated to work well and have high loyalty to the company. Employees will see their career development based on the experience they got while working at the company concerned. How employees perceive their responsibilities, titles and powers will affect their level of commitment. This is in accordance with the opinion of Siagian (2014) which states that if employees see and assess that their career prospects in the company are bright, they will be motivated to be more productive at work, have strong motivation, loyal and have a high work commitment within the company. High work commitment will be owned by employees, if the company is promising in terms of career development, but it is different from companies that do not promise career development for their employees (Siagian, 2014). Therefore, career development will not only stimulate employee motivation but also make employees want to continue working at the company and help the company achieve its goals. This is in accordance with the results of research conducted by Budi (2017) which shows that career development has a positive and significant effect on employee commitment. Armawati's research (2017) shows that career development has a positive and significant effect on the organizational commitment of employees of PT. Panin Bank Pekanbaru Branch Office. Employees will have a high work commitment, if the company is promising in terms of career development, but it is different from companies that do not promise career development for their employees (Siagian, 2014). Therefore, career development will not only stimulate employee motivation but also make employees want to continue working at the company and help the company achieve its goals. This is in accordance with the results of research conducted by Budi's research (2017) which shows that career development has a positive and significant effect on employee commitment. Armawati's research (2017) shows that career development has a positive and significant effect on the organizational commitment of employees of PT. Panin Bank Pekanbaru Branch Office. Employees will have a high work commitment if the company promises to develop their career, but it is different from companies that do not promise career development for their employees (Siagian, 2014). Therefore, career development will not only stimulate employee motivation but also make employees want to continue working at the company and help the company achieve its goals. This is in accordance with the results of research conducted by Budi's research (2017) which shows that career development has a positive and significant effect on employee commitment. Armawati's research (2017) shows that career development has a positive and significant effect on the organizational commitment of employees of PT. Panin Bank Pekanbaru Branch Office. if the company is promising in terms of career development, but it is different from companies that do not promise career development for employees (Siagian, 2014). Therefore, career development will not only stimulate employee motivation but also make employees want to continue working at the company and help the company achieve its goals. This is in accordance with the results of research conducted by Budi's research (2017) which shows that career development has a positive and significant effect on employee commitment. Armawati's research (2017) shows that career development has a positive and significant effect on the organizational commitment of employees of PT. Panin Bank Pekanbaru Branch Office. if the company is promising in terms of career development, but it is different from a company that does not promise career development for its employees (Siagian, 2014). Therefore, career development will not only stimulate employee motivation but also make employees want to continue working at the company and help the company achieve its goals. This is in accordance with the results of research conducted by Budi's research (2017) which shows that career development has a positive and significant effect on employee commitment. Armawati's research (2017) shows that career development has a positive and significant effect on the organizational commitment of employees of PT. Panin Bank Pekanbaru Branch Office. however, it is different from companies that do not promise career development for their employees (Siagian, 2014). Therefore, career development will not only stimulate employee motivation but also make employees want to continue working at the company and help the company achieve its goals. This is in accordance with the results of research conducted by Budi's research (2017) which shows that career development has a positive and significant effect on employee commitment. Armawati's research (2017) shows that career development has a positive and significant effect on the organizational commitment of employees of PT. Panin Bank 
Pekanbaru Branch Office. however it is different from companies that do not promise career development for their employees (Siagian, 2014). Therefore, career development will not only stimulate employee motivation but also make employees want to continue working at the company and help the company achieve its goals. This is in accordance with the results of research conducted by Budi's research (2017) which shows that career development has a positive and significant effect on employee commitment. Armawati's research (2017) shows that career development has a positive and significant effect on the organizational commitment of employees of PT. Panin Bank Pekanbaru Branch Office. This is in accordance with the results of research conducted by Budi (2017) which shows that career development has a positive and significant effect on employee commitment. Armawati's research (2017) shows that career development has a positive and significant effect on the organizational commitment of employees of PT. Panin Bank Pekanbaru Branch Office. This is in accordance with the results of research conducted by Budi's research (2017) which shows that career development has a positive and significant effect on employee commitment. Armawati's research (2017) shows that career development has a positive and significant effect on the organizational commitment of employees of PT. Panin Bank Pekanbaru Branch Office.

The influence of transformational leadership on performance, namely: the most important function of leadership is to provide motivation to subordinates, transformational leadership is believed to have an influence on an organization, institution or company in non-financial forms such as job satisfaction and employee performance. Transformational leaders motivate their employees to perform an unexpected performance through transforming their thoughts and attitudes in achieving performance beyond expectations, one of the behaviors that must be shown by a transformational leader is the influence of idealism, motivation, intellectual stimulation and individual consideration.Robbins, 2015).

The leader has the responsibility to create conditions and incentives that motivate members to achieve specified goals. Motivation or encouragement can have an impact on positive behavior, namely providing morale or a negative impact, namely pressure. A person's leadership style affects a person's ability to influence individuals or groups, so that the behavior of subordinates is in accordance with the goals of the organization, so there must be a combination of motivation to fulfill their own needs and organizational demands. Effective leaders are leaders who recognize the important strengths contained in the leadership of a group and the flexibility in the approach they use to carry out these leadership tasks which can lead to motivation that can improve the performance of their subordinates (Hasibuan, 2012). This is in accordance with the results of research conducted by Research by Dewi (2018) showing that leadership has a significant effect on employee performance. Septyan's research (2016) shows that transformational leadership has a significant effect on employee performance.

Ameliany's research (2016) found that there is a direct effect of career development on performance, this proves that the better career development can improve employee performance in work, on the other hand, if low career development can reduce employee performance at work. In this research, career development includes career management and career planning. In career management, it shows that the institution provides training to employees with an alternate system every year, if last year they received training, this year they did not receive training anymore, this is due to lack of college funding. adequate if it provides training to all employees every year. The career planning dimension shows that the institution provides educational programs to employees. Ratanto's research (2015) found that career development actors are most predominantly related to performance. This research shows the importance of providing career development opportunities for achievement. Providing career development opportunities should be related to their expertise so that they can be transmitted to others, so that the knowledge they get can be used to improve performance. According to Husaini (2017) states that sa company is like the organization within it there is an organizational structure such as leaders or superiors and subordinates or children fruit, in a company, commitment between leaders or subordinates will be mutual related to where the cooperation and loyalty between leaders and subordinates can resulting in increased performance. In this case, a strong emotional commitment and bond to the company has an important role in the improvement performance. High commitment of an employee will have an effect on performance employees. This is in accordance with the opinion of Meyer et al (1993) in Panggabean 2012 which states that those who have a high continuan commitment stay because they feel they need it, while employees who have a high affective commitment stay because they want it and the normative commitment remains because they felt he should have done so.

Research Husaini (2017) found that organizational commitment consisting of continuous commitment, affective commitment and normative commitment has an influence on the performance of the Nurse Pavilliun Cendana Hospital Dr. Moewardi Surakarta. Efliani's research (2015) also found that there was a significant effect of organizational commitment on the performance of nurses at the Regional General Hospital Dr. Moewardi Central Java.These findings support the results of research conducted by Wicaksana (2016) found that organizational commitment has a positive effect on the performance of nurses at the Yogyakarta Islamic Hospital.

\subsection{Hypothesis}

- Transformational leadership berpositive influence on organizational commitment.

- Career development positive effect on employee organizational commitment

- Transformational leadership berpositive influence on employee performance

- Career development positive effect on employee performance

- Organizational commitment has a positive effect on employee performance 


\section{Research Methods}

\subsection{Research Design}

The research design is a flow of research activities to provide solutions using a quantitative approach carried out by survey (Margono, 2010). Survey research with a questionnaire as the main research instrument is designed in this study to explain (explanation) the relationship of the variables studied, namely: transformational leadership, career development, organizational commitment and employee performance.

\subsection{Location and Object of Research}

The research conducted took place at the Klungkung District Health Office. The research objects are transformational leadership, career development, organizational commitment and employee performance.

\subsection{Time and Scope of Research}

This research was conducted in the first week of January to February 2020. The scope of this research will examine transformational leadership and career development on employee performance with organizational commitment as a mediating variable. Where the research is carried out at the Klungkung District Health Office, it has an organizational structure, namely leaders and other employees in carrying out operational activities require a good understanding of the various variables to be studied.

\subsection{Population and Sample}

The population in this study were all civil servants, namely nurses and other functional personnel such as health administrators, health educators, public health and environmental health workers who work at the Klungkung District Health Office, totaling 82 people. In general, a population whose size is below 100 should be taken entirely as a sample, while a population greater than 100 can be taken $10 \%-20 \%$ or $20 \%-30 \%$. Then taken entirely so that the research is a population study (saturated sample). The number of samples in this study were 82 people.

\subsection{Identification of Research Variables}

The variables involved and used in this study are as follows:

- Exogenous variables are variables whose value variations are not influenced by other variables, and are able to influence the value variations of other variables which are generally given the $\mathrm{X}$ symbol. The exogenous variables in this study are transformational leadership (X1) and career development (X2).

- Endogenous variables (endogenous variables) are variables whose value variations are influenced by other variables (exogenous / free variables) which are generally given the symbol Y. Endogenous variables in this study are organizational commitment (Y1) and employee performance (Y2).

- In addition, it can be identified that the mediating variables in this research model are: organizational commitment (Y1).

\subsection{Data Collection Methods and Research Instruments}

The data collection method used in this study was a questionnaire. The questionnaire is a data collection method by distributing a questionnaire to respondents who are submitted in writing to customers to get answers or responses and the necessary information related to the variables studied. The data were collected to be used as predictor information for the causality of each variable, namely competence, career development and job satisfaction using a questionnaire measured by a Likert scale.

Data analysis technique Inferential analysis techniques are used to test the empirical model and the hypotheses proposed in this study. The analysis technique used is a structural equation modeling (Structural Equation Modeling SEM) based on variance or component-based SEM, known as Partial Least Square (PLS). PLS is a powerful analysis method, because it does not assume the data must use a certain scale measurement, is used on a small sample size (30 - 50 units or < 100 units), and can also be used for theory confirmation (Ghozali, 2014, Hair et al., 2014).

\section{Research Results and Discussion}

\subsection{Inferential Analysis Results}

Inferential analysis using Smart Partial Least Square (Smart PLS). Based on the results of data processing using PLS, then evaluating the structural equation model. In this evaluation, there are two basic evaluations, namely: 1) evaluation of the measurement model (outer model) to determine the validity and reliability of indicators measuring latent variables, and 2) evaluation of the structural model (inner model) to determine the accuracy of the model. Before the evaluation of the model is carried out, it can be reiterated that the questionnaire as a means of collecting data in this study is an instrument that has been valid and reliable.

\subsection{Evaluation of Measurement Model (Outer Model)}

The results of the Outer Model analysis which include convergent, discrete validity and composite reliability can be presented as follows: 


\subsubsection{Convergent Validity}

The indicator is considered valid if it has an outer loading value above 0.50 and or a T-Statistics value above 1.96 . As for the results of the outer model examination, it can be seen that the outer loading of each indicator on a variable is shown in Table 1 below

\begin{tabular}{|c|c|c|c|}
\hline Variable & Indicator & $\begin{array}{c}\text { Outer } \\
\text { Loading }\end{array}$ & T-Statistic \\
\hline \multirow{4}{*}{$\begin{array}{c}\text { Transformational } \\
\text { leadership (X1) }\end{array}$} & Charismatic Leadership (X1.1) & 0.900 & 22,483 \\
\hline & Inspirational Motivation (X1.2) & 0.716 & 8,417 \\
\hline & Intellectual stimulation (X1.3) & 0.811 & 14,938 \\
\hline & Individualized consideration (X1.4) & 0.643 & 5,887 \\
\hline \multirow{2}{*}{$\begin{array}{c}\text { Career } \\
\text { development (X2) }\end{array}$} & Career Management (X1.1) & 0.900 & 29,270 \\
\hline & Career Planning (X1.2) & 0.693 & 3,787 \\
\hline \multirow{3}{*}{$\begin{array}{l}\text { Organizational } \\
\text { Commitment (Y1) }\end{array}$} & Affective Commitment (Y1.1) & 0.911 & 26,435 \\
\hline & Continuous commitment (Y1.2) & 0.844 & 11,565 \\
\hline & Normative Commitment (Y1.3) & 0.696 & 8,302 \\
\hline \multirow{5}{*}{$\begin{array}{c}\text { Employee } \\
\text { Performance (Y2) }\end{array}$} & Job Performance (Y2.1) & 0.680 & 8,202 \\
\hline & Responsible (Y2.2) & 0.837 & 36,902 \\
\hline & Obedience (Y2.3) & 0.564 & 3,361 \\
\hline & Honesty (Y2.4) & 0.579 & 3,871 \\
\hline & Cooperate (Y2.5) & 0.820 & 15,721 \\
\hline
\end{tabular}

Based on the information in Table 1 above, it can be seen that the four indicators measure the variable ktransformational leadership(X1) has an outer loading value greater than 0.50 and a Tstatistic above 1.96. This means, Charismatic Leadership (X1.1), Inspirational Motivation (X1.2), Intellectual stimulation (X1.3) andIndividualized consideration (X1.4) is a valid indicator as a measure of variable transformational leadership(X1). In addition, the Charismatic Leadership (X1.1) indicator is the strongest indicator of variable ktransformational leadership(X1) because it has the largest outer loading value (0.900). The evaluation results of the career development variable (X2) can be reported that career management (X2.1) and career development are valid indicators in reflecting career development variables (X2), because it is proven that all of these indicators have an outer loading value greater than 0.50 , and T- Statistics above 1.96. Meanwhile, the career management indicator (X2.1) is the strongest indicator reflecting career development (X2) with an outer loading value of 0.900 . In evaluating the organizational commitment variable (Y1), it appears that the three indicators have outer loading values above 0.50 and the T-Statistic is far above 1.96. These results indicate that affective commitment (Y1.1); ongoing commitment (Y1.2) and normative commitment (Y1. 3) is a valid indicator as a measure of the organizational commitment variable (Y1). Further analysis shows affective commitment (Y1.1) is the strongest indicator reflecting organizational commitment (Y1) with an outer loading value of 0.911 . The results of examination of the employee performance variable (Y2) show that all indicators have an outer loading value greater than 0.50 and the TStatistic is far above 1.96. This provides an indication that work performance (Y2.1), responsibility (Y2.2), obedience (Y2.3), honesty (Y2.4) and cooperation (Y2.5) are valid indicators as measuring employee performance variables ( Y2). Furthermore, he said that responsibility (Y2.2) is the strongest indicator reflecting employee performance (Y2) with an outer loading value of 0.837 . Further analysis shows affective commitment (Y1.1) is the strongest indicator reflecting organizational commitment (Y1) with an outer loading value of 0.911 . The results of examining the employee performance variable (Y2) show that all indicators have an outer loading value greater than 0.50 and the T-Statistic is far above 1.96. This provides an indication that work performance (Y2.1), responsibility (Y2.2), obedience (Y2.3), honesty (Y2.4) and cooperation (Y2.5) are valid indicators as measuring employee performance variables ( Y2). Furthermore, he said that responsibility (Y2.2) is the strongest indicator reflecting employee performance (Y2) with an outer loading value of 0.837. Further analysis shows affective commitment (Y1.1) is the strongest indicator reflecting organizational commitment (Y1) with an outer loading value of 0.911 . The results of examining the employee performance variable (Y2) show that all indicators have an outer loading value greater than 0.50 and the T-Statistic is far above 1.96. This provides an indication that work performance (Y2.1), responsibility (Y2.2), obedience (Y2.3), honesty (Y2.4) and cooperation (Y2.5) are valid indicators as measuring employee performance variables ( Y2). Furthermore, he stated that responsibility (Y2.2) is the strongest indicator that reflects employee performance (Y2) with an outer loading value of 0.837 . The results of examining the employee performance variable (Y2) show that all indicators have an outer loading value greater than 0.50 and the TStatistic is far above 1.96. This provides an indication that work performance (Y2.1), responsibility (Y2.2), obedience (Y2.3), honesty (Y2.4) and cooperation (Y2.5) are valid indicators as measuring employee performance variables ( Y2). Furthermore, he said that responsibility (Y2.2) is the strongest indicator reflecting employee performance (Y2) with an outer loading value of 0.837 . The results of examining the employee performance variable (Y2) show that all indicators have an outer loading value greater than 0.50 and the T-Statistic is far above 1.96. This provides an indication that work performance (Y2.1), responsibility (Y2.2), obedience (Y2.3), honesty (Y2.4) and cooperation (Y2.5) are valid indicators as measuring employee performance variables ( Y2). Furthermore, he said that responsibility (Y2.2) is the strongest indicator reflecting employee performance (Y2) with an outer loading value of 0.837. 5) is a valid indicator as a measure of employee performance variables (Y2). Furthermore, he said that responsibility (Y2.2) is the strongest indicator reflecting 
employee performance (Y2) with an outer loading value of 0.837. 5) is a valid indicator as a measure of employee performance variables (Y2). Furthermore, he stated that responsibility (Y2.2) is the strongest indicator that reflects employee performance (Y2) with an outer loading value of 0.837.

\subsubsection{Discriminant Validity}

This evaluation is done by comparing the square root of average variance extracted $(\sqrt{ }$ AVE) value of each latent variable with the correlation between other latent variables in the model. The stipulation is that if the square root of average variance extracted $(\sqrt{ } \mathrm{AVE})$ the latent variable is greater than the latent variable correlation coefficient, it indicates that the variable indicators have good discriminant validity. The recommended AVE value is greater than 0.50 . The results of discriminant validity examination (Table 5.12) show that the AVE value is greater than 0.50, and the four latent variables studied have a larger square root of average variance extracted $(\sqrt{\mathrm{AVE}})$ value with a correlation coefficient between other variables. Thus, the results obtained indicate good discriminant validity.

\begin{tabular}{|c|c|c|c|c|c|c|}
\hline Variable & AVE & $\sqrt{\text { AVE }}$ & \multicolumn{3}{|c|}{ Correlation } \\
\cline { 3 - 6 } & & & X1 & X2 & Y1 & Y2 \\
\hline $\begin{array}{c}\text { Transformational } \\
\text { leadership (X1) }\end{array}$ & 0.598 & 0.773 & 1,000 & & & \\
\hline $\begin{array}{c}\text { Career } \\
\text { Development (X2) }\end{array}$ & 0.645 & 0.803 & 0.267 & 1,000 & & \\
\hline $\begin{array}{c}\text { Organizational } \\
\text { Commitment (Y1) }\end{array}$ & 0.543 & 0.736 & 0.381 & 0.359 & 1,000 & \\
\hline $\begin{array}{c}\text { Employee } \\
\text { Performance (Y2) }\end{array}$ & 0.577 & 0.760 & 0.445 & 0.893 & 0.496 & 1,000 \\
\hline
\end{tabular}

Table 2: Discriminant Validity Check

Composite Reliability. Composite Reliability aims to evaluate the reliability value between the indicator blocks of the constructs that form it. The results of the composite reliability assessment in the measurement model (Table 5.13), it appears that the composite reliability value of the four latent variables is above 0.70 , so the indicator block is declared reliable in measuring the variables.

\begin{tabular}{|c|c|c|}
\hline Variable & Composite Reliability & T-Statistic \\
\hline Transformational leadership (X1) & 0.854 & 30,352 \\
\hline Career development (X2) & 0.782 & 9,762 \\
\hline Organizational Commitment (Y1) & 0.754 & 17,735 \\
\hline Employee Performance (Y2) & 0.814 & 15,790 \\
\hline
\end{tabular}

Table 3: Result Composite Reliability

In accordance with the results of the convergent evaluation, the discriminant validity of each indicator, and the composite reliability for the indicator blocks obtained, it can be concluded that the indicators for each latent variable are valid and reliable measures. The next step, an inner model analysis is carried out to determine the suitability of the model (goodness of fit model) in this study

\subsection{Evaluation of the Structural Model (Inner Model)}

The structural model is evaluated by paying attention to the Q2 predictive relevance model which measures how well the observation value is generated by the model. Q2 is based on the coefficient of determination of all dependent variables. The quantity of Q2 has a value with a range of $0<\mathrm{Q} 2<1$, the closer to the value of 1 , the better the model. In this structural model, there are two endogenous (dependent) variables, namely: organizational commitment (Y1) and employee performance (Y2), so that two determination coefficients (R2) can be determined which are used as the basis for calculating the Q2 predictive relevance model according to Table 4 below.

\begin{tabular}{|c|c|c|}
\hline Structural Model & Dependent Variable & R-square \\
\hline 1 & Organizational Commitment $(\mathrm{Y} 1)$ & 0.860 \\
\hline 2 & Employee Performance $(\mathrm{Y} 2)$ & 0.216 \\
\hline \multicolumn{3}{|c|}{ Calculation: Q2 $=(1-[(1-\mathrm{R} 12)(1-\mathrm{R} 22)]$} \\
& $\mathrm{Q} 2=(1-[(1-0,860)(1-0,216)]=0.8902$ & \\
\hline
\end{tabular}

Table 4: Result of Structural Model Evaluation (Inner Model)

Based on the data presentation above in Table 4 above, it is proven that the value of Q2 $=0.8902$ is close to the value of 1 , thus the results of this evaluation provide evidence that the structural model has a good goodness-fit model. These results can be interpreted that the information contained in the data, $89.02 \%$ can be explained by the model while the remaining $10.98 \%$ is explained by errors or other variables not contained in the model. 


\subsection{Hypothesis Testing Results}

Hypothesis testing is done by t-test by sorting for testing the direct and indirect effects or testing the mediating variables. The following sections describe the results of the direct effect test and examination of the mediating variables, respectively.

Hypothesis Test Direct Effect. The recapitulation of the results of the path coefficient validation test on each path for the direct effect presented in Table 5 provides information for testing the following hypothesis:

\begin{tabular}{|c|c|c|c|c|}
\hline No. & Relations between Variables & $\begin{array}{c}\text { Path } \\
\text { Coefficient }\end{array}$ & T Statistics & Ket \\
\hline 1 & $\begin{array}{c}\text { Transformational leadership X1 -> } \\
\text { Organizational Commitment Y1 }\end{array}$ & 0.307 & 2,539 & Significant \\
\hline 2 & $\begin{array}{c}\text { X2 career development -> Organizational } \\
\text { Commitment Y1 }\end{array}$ & 0.277 & 2,228 & Significant \\
\hline 3 & $\begin{array}{c}\text { Transformational leadership X1 -> } \\
\text { Employee Performance Y2 }\end{array}$ & 0.179 & 3,167 & Significant \\
\hline 4 & $\begin{array}{c}\text { Career development X2 -> Employee } \\
\text { Performance Y2 }\end{array}$ & 0.794 & 17,267 & Significant \\
\hline 5 & $\begin{array}{c}\text { Organizational Commitment Y1 -> } \\
\text { Employee Performance Y2 }\end{array}$ & 0.143 & 2,321 & Significant \\
\hline
\end{tabular}

Table 5: Hypothesis Testing Results Direct Effect

Information from the recapitulation of the analysis above can determine the results of hypothesis testing as follows:

- $\quad$ Based on Table 5 above shows transformational leadership (X1) proved to have a positive and significant effect on organizational commitment (Y1). This result is shown by the positive path coefficient of 0.307 with T-statistic $=2.539$ (T-statistic $>1.96)$, so hypothesis 1 (H1):transformational leadershippositive effect on organizational commitment can be proven. The results of the analysis obtained mean that the better the leadership at the Klungkung District Health Office will increase the commitment of employees to the organization.

- Based on Table 5 above shows career development (X2) proved to have a positive and significant effect on organizational commitment (Y1). This result is indicated by a positive path coefficient of 0.277 with a Tstatistic $=2.228$ (T-statistic $>1.96)$, so hypothesis $2(\mathrm{H} 2)$ :career development positive effect on organizational commitment can be proven. The results of the analysis obtained mean that the better the career development of employees at the Klungkung District Health Office will increase the commitment of employees to the organization

- $\quad$ Based on Table 5 above shows transformational leadership (X1) proved to have a positive and significant effect on employee performance (Y2). This result is shown by the positive path coefficient of 0.179 with Tstatistic $=3.167$ (T-statistic $>1.96)$, so that hypothesis 3 (H3):transformational leadership positive effect on employee performance can be proven. The results of the analysis obtained mean that the better the leadership at the Klungkung District Health Office will improve the performance of employees in carrying out their main duties.

- $\quad$ Based on Table 5 above shows career development (X2) proved to have a positive and significant effect on employee performance (Y2). This result is shown by the positive path coefficient of 0.794 with T-statistic = 17.267 (T-statistic> 1.96), so hypothesis 4 (H4):career development positive effect on employee performance can be proven. The results of the analysis obtained mean that the better the career development of employees at the Klungkung District Health Office will improve employee performance in carrying out tasks which are their main duties.

- $\quad$ Based on Table 5 above shows organizational commitment (Y1) proved to have a positive and significant effect on employee performance (Y2). This result is shown by the positive path coefficient of 0.143 with Tstatistic $=2.321$ (T-statistic $>1.96)$, so that hypothesis 5 (H5):organizational commitment positive effect on employee performance can be proven. The results of the analysis obtained mean that the higher the commitment of employees to the organization will increase the performance of employees in carrying out the tasks which are the main duties and functions of the Klungkung District Health Office.

The full model of the SEM-PLS analysis results is presented in Figure 1 below 


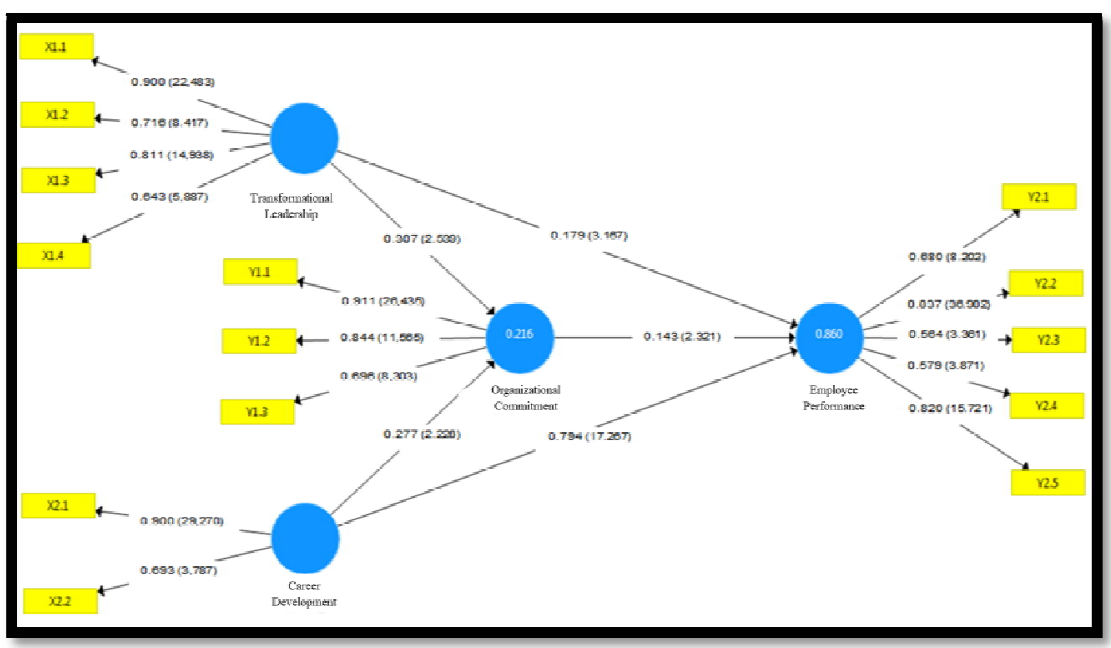

Figure 1: Full Model SEM PLS Analysis Results

\subsubsection{Examination of Mediation Variables}

BIn the following, we will examine the mediating role of the organizational commitment variable (Y1) on the indirect effect transformational leadership (X1) and career development (X2) on employee performance (Y2). As for the examination of the indirect effect in this study, the results of the analysis are presented in Table 6

\begin{tabular}{|c|c|c|c|c|c|c|}
\hline No. & Variable Mediation Organizational & \multicolumn{5}{|c|}{ Effect Coefficient } \\
\cline { 3 - 7 } & Commitment (Y1) & A & B & C & D & Ket \\
\hline 1 & Transformational leadership X1 -> & 0.307 & 0.277 & 0,179 & 0.143 & No. \\
& Employee Performance Y2) & $(\mathrm{sig})$ & $(\mathrm{sig})$ & $(\mathrm{sig})$ & $(\mathrm{sig})$ & Mediation \\
\hline 2 & Career development X2 -> Employee & 0.794 & 0.845 & 0.227 & 0.143 & No. \\
& Performance Y2 & $(\mathrm{sig})$ & $(\mathrm{sig})$ & $(\mathrm{sig})$ & $(\mathrm{sig})$ & Mediation \\
\hline
\end{tabular}

Table 6: Recapitulation of Test Results for Mediation Variables Information: Significance (Sig) $=$ T statistic $>1.96$ at $\alpha=5 \%$

Information that can be obtained from Table 5.16 above can be presented in the following description:

- Organizational commitment (Y1) has not been able to mediate the indirect effect transformational leadership (X1) on employee performance (Y2). The results of the mediation examination on effect A; C; and D already have a significant value, but the path coefficient of the indirect effect obtained is still very small, which is 0.044 (below $0.10)$. Based on these results it can be stated, the organizational commitment obtained from transformational leadership have not been able to determine the performance of employees at the Klungkung District Health Office.

- Organizational commitment (Y1) has not been able to mediate the indirect effect career development (X2) on employee performance (Y2). The results of the mediation examination on effect A; C; and D has a significant value, but the path coefficient of the indirect effect obtained is still very small, which is 0.040 (below 0.10 ). Based on these results it can be stated, the organizational commitment obtained from good career development have not been able to determine the performance of employees at the Klungkung District Health Office.

The results of the analysis as a whole can be recapitulated from the direct effect, indirect effect, and total effect in the following Table 7.

\begin{tabular}{|c|c|c|c|c|}
\hline No. & Variable & $\begin{array}{c}\text { Live } \\
\text { Effects }\end{array}$ & $\begin{array}{c}\text { Indirect } \\
\text { Effects }\end{array}$ & $\begin{array}{c}\text { Total } \\
\text { Effect }\end{array}$ \\
\hline 1 & $\begin{array}{c}\text { Transformational leadership X1 -> } \\
\text { Organizational Commitment Y1 }\end{array}$ & $0.307 \mathrm{~S}$ & - & 0.307 \\
\hline 2 & $\begin{array}{c}\text { Transformational leadership X1 -> } \\
\text { Employee Performance Y2 }\end{array}$ & $0.179 \mathrm{~S}$ & $\begin{array}{c}0.044 \mathrm{~S}\left(0.307^{*}\right. \\
0.141)\end{array}$ & 0.223 \\
\hline 3 & $\begin{array}{c}\text { X2 career development -> } \\
\text { Organizational Commitment Y1 }\end{array}$ & $0.277 \mathrm{~S}$ & - & 0.277 \\
\hline 4 & $\begin{array}{c}\text { Career development X2 -> Employee } \\
\text { Performance Y2 }\end{array}$ & $0.794 \mathrm{~S}$ & $\begin{array}{c}0.040 \mathrm{~S}\left(0.277^{*}\right. \\
0.143)\end{array}$ & 0.834 \\
\hline 5 & $\begin{array}{c}\text { Organizational Commitment Y1 -> } \\
\text { Employee Performance Y2 }\end{array}$ & $0.143 \mathrm{~S}$ & - & 0.143 \\
\hline
\end{tabular}

Table 7: Direct, Indirect and Total Effect Calculations

Information obtained from Table 7 above, the career development path (X2) on employee performance (Y2) has the greatest total effect, which is 0.834 compared to the pathway transformational leadership (X1) on employee performance (Y2) which only has a total effect of 0.223 . These results indicate that employee performance at the Klungkung District Health Office tends to be determined by employee career development.Career development (such as 
promotion or promotion) that is done well so that employees get better rights than what was previously obtained, both material and non-material able to directly improve employee performance, a sign of seeing employee commitment to the organization.

Other findings obtained, transformational leadership will be able to further improve the performance of employees at the Klungkung District Health Office, if the employees have a higher commitment to the organization. Thus, employee commitment is higher in organizations based on leadershiptransformationalwill further improve the performance of employees in carrying out their duties at the Klungkung District Health Office.

\section{Discussion}

In accordance with the results of data processing described above, this section will discuss one by one regarding: 1) transformational leadership has a positive effect on organizational commitment; 2). Career development has a positive effect on employee organizational commitment. 3). Transformational leadership has a positive effect on employee performance. 4) career development has a positive effect on employee performance. 5). career development has a positive effect on employee performance

Based on the results of the analysis of the effect of transformational leadership on organizational commitment, it shows that transformational leadershippositive effect on organizational commitment, the results of this test indicate that hypothesis $1(\mathrm{H} 1)$ is accepted. These findings indicate that the level of commitment employees have to the organization is influenced by their perceptions of transformational leadership styles. The higher the transformational leadership, the higher the employee's organizational commitment. This can be seen from the results of the highest indicator valuetransformational leadership is charismatic leadershipwhere a leader who respects each employee as an individual so that employees feel reluctant. so that it can be interpreted that employees are committed to the organization because of the employees' reluctance or respect for their leaders who treat employees as respected individuals. Therefore, the more leaders apply charismatic leadership, the higher employee commitment to the organization.

The results of this study are supported by theory Hasibuan (2012) khe success of an organization or company is determined by a leader who leads the organization. A leader with transformational leadership has a vision for the future and is able to identify environmental changes and is able to transform these changes into the organization. Transformational leadership also provides inspiration and motivation in employees, so that it can create high organizational commitment. An employee who has a high commitment will have an identification with the organization, are seriously involved in work and there is loyalty and positive affection for the organization. However, in reality the civil servants in the Klungkung District Health Office have a low affective commitment, it can be seen when there is supervision from their superiors, almost all civil servants work their best, however, when they are not supervised, the civil servants will work as they please. This shows that employees do not fully believe in the company and are willing to accept the company's values. Thus it can be concluded that if a leader has the ability to mobilize and empower employees, it can affect organizational commitment

The results of this study are in line with the results of research by Kesuma (2018) showing that transformational leadership has a positive and significant effect on organizational commitment. Ahmad's research (2016) states that there is a positive effect of transformational leadership style with performance on organizational commitment as an intervening variable. This shows that the better the leadership style is applied, the higher the organizational commitment, which has an impact on improving its performance.

Based on the analysis of the effect of career development on organizational commitment, it shows that career development has a positive and significant effect on organizational commitment, the results of this test indicate that hypothesis $2(\mathrm{H} 2)$ is accepted. This result means that career development will assist employees in making themselves committed to the organization or company. Whether or not employees in career development will have an impact on work commitment. This can be seen from the results of the highest indicator value of career development is career management so that they have the opportunity to improve their career according to performance through good employee career management such as training, promotion of positions and others so as to increase the actualization and realize their rights as a civil servant. This is in accordance with the conditions in the Klungkung District Health Office that employees, especially civil servants, already have a clear career path and are well implemented by management, one of which is that every civil servant is given the opportunity to increase his / her potential by participating in continuous education and training.

The results of this study are supported by the theory of Zurnali (2014). One of the factors in the formation of work commitment is career development. Therefore, the company must make a career development system as best as possible. The employees are still motivated to work well and have high loyalty to the company. Employees will see their career development based on the experience they got while working at the company concerned. How employees perceive the responsibilities, titles and powers they have will affect their level of commitment. This is in accordance with the opinion of Siagian (2014) which states that if employees see and assess that their career prospects in the company are bright, they will be motivated to be more productive at work, have strong motivation, loyal and have a high work commitment within the company. Employees will have a high work commitment if the company promises to develop their career, but it is different from companies that do not promise career development for their employees (Siagian, 2014). Therefore, career development will not only stimulate employee motivation but also make employees want to continue working at the company and help the company achieve its goals.

The results of this study are in line with the results of research by Budi (2017) showing that career development has a positive and significant effect on employee commitment. Armawati's research (2017) shows that career 
development has a positive and significant effect on the organizational commitment of employees of PT. Panin Bank Pekanbaru Branch Office..

Based on the results of the analysis of the effect of transformational leadership on employee performance, it shows that transformational leadership has a positive and significant effect on employee performance, the results of this test indicate that hypothesis 3 (H3) is accepted. These findings indicate that the stronger the understanding and implementation of transformational leadership, the stronger employee performance. This gives an idea that the leadership that has been carried out, is carried out well. That the leadership has had a positive effect on employees at work. Leaders also routinely provide advice or direction needed by employees so as to facilitate the employee's performance.

On the other hand, organizational commitment has not been able to mediate on the indirect effect transformational leadership on employee performance. Based on these results it can be stated, the organizational commitment obtained fromtransformational leadership have not been able to determine the performance of employees at the Klungkung District Health Office, so these results can be interpreted that the influence of a leader in improving employee performance is very important so that a leader must have the values contained in the criteria for transformational leaders.

In an effort to support the achievement of organizational goals, the leadership at the Klungkung District Health Office provides complete information about the correct work implementation instructions on a regular basis, then supervises and corrects the work results of each employee so that the error rate that occurs can be reduced to a minimum. The Head of the Klungkung District Health Office has provided a good example by always arriving on time, looking neat and attractive, often greeting and being friendly to every employee in the office. In addition, always be fast and decisive in making decisions when there are problems in the organization. For example, if there are employees who are fighting, it can be a good mediator in providing a fair solution for both parties. Each chair the meeting held; the head of the Klungkung District Health Office has been firm in making organizational decisions. In making these decisions through deliberation to reach consensus, and employees who are appointed as representatives are given the opportunity to participate in providing input or opinions that are useful to the company.

The results of this study are supported by theory Robbins (2015) The most important function of leadership is to provide motivation to subordinates, transformational leadership is believed to have an influence on an organization, institution or company in non-financial forms such as job satisfaction and employee performance. Transformational leaders motivate their employees to perform a performance beyond expectations through the transformation of their thoughts and attitudes in achieving performance beyond expectations, one of the behaviors that must be demonstrated by a transformational leader is the influence of idealism, motivation, intellectual stimulation and individual consideration.

The leader has the responsibility to create conditions and incentives that motivate members to achieve specified goals. Motivation or encouragement can have an impact on positive behavior, namely providing morale or a negative impact, namely pressure. A person's leadership style affects a person's ability to influence individuals or groups, so that the behavior of subordinates is in accordance with the goals of the organization, so there must be a combination of motivation to fulfill their own needs and organizational demands.

The results of this study are in line with the results of research conducted by Research by Dewi (2018) showing that leadership has a significant effect on employee performance. Septyan's research (2016) shows that transformational leadership has a significant effect on employee performance.

Based on the analysis of the effect of career development on employee performance, it shows that career development has a significant effect on employee performance, the results of this test indicate that hypothesis 4 (H4) is accepted. This result means that career development can improve the performance of employees at the Klungkung District Health Office. This is because the career development of an employee as a State Civil Apparatus has been regulated in regulations so that career development is clear and there are no obstacles experienced.

On the other hand korganizational commitment has not been able to mediate the indirect effect career development on employee performance. Based on these results it can be stated, the organizational commitment obtained fromgood career development have not been able to determine the performance of employees at the Klungkung District Health Office. The findings of this study prove that the high and low performance Klungkung District Health Office determined by employee career development. Aim of all career development programs is to fit between needs and goals of employees with career opportunities available at Klungkung District Health Office. Therefore, career development establishment efforts welldesigned ones will assist employees in determining their own career needs, and adjust between the needs of employees with the intention of Klungkung District Health Office. Career development will affect employee performance in carry out the task. Better career development experienced by employees will certainly have a positive impact on improving employee performance the.

Career development shows the development of an individual employee in the level of position or rank achieved during the employee's work or experience during his tenure in an organization. On the other hand, career can also show each individual with their role or status in the organization. Career development is aimed at seeing a person's career advancement from one level to another. This is in accordance with Handoko's statement (2012) where career development is personal improvements that a person makes to achieve a career plan. Prihansa (2016) argues that with career planning and development, clear benefits for employees are satisfaction, personal development, and a quality work life.

The results of this study are in line with the results of research studies Ameliany (2016) found that There is a direct effect of career development on performance, this proves that the better career development can improve employee performance in work, on the other hand, if low career development can reduce employee performance at work. In this research, career development includes career management and career planning. In career management, it shows that the institution provides training to employees with an alternate system every year, if last year they received training, this year 
they did not receive training anymore, this is due to lack of college funding. adequate if it provides training to all employees every year. The career planning dimension shows that the institution provides educational programs to employees. Ratanto's research (2015) found that career development actors are most predominantly related to performance. This research shows the importance of providing career development opportunities for achievement. Providing career development opportunities should be related to their expertise so that they can be transmitted to others, so that the knowledge they get can be used to improve performance.

Based on the results of the analysis of the effect of organizational commitment on employee performance, it shows that organizational commitment has a significant and positive effect on employee performance, the results of this test indicate that hypothesis 5 (H5) is accepted. This means that very high organizational commitment can improve the performance of employees who work at the Klungkung District Health Office. This is because the Klungkung District Health Office is no different than an organization in which there is an organizational structure such as leaders or superiors and subordinates or subordinates, within the company, the commitment between leaders or subordinates is interrelated where cooperation and loyalty between leaders and subordinates may result in increased performance. In this case, commitment and strong emotional ties to the company have an important role in improving performance. High commitment of an employee will affect employee performance.

According to Husaini (2017) states that sa company is like the organization within it there is an organizational structure such as leaders or superiors and subordinates or children fruit, in a company, commitment between leaders or subordinates will be mutual related to where the cooperation and loyalty between leaders and subordinates can resulting in increased performance. In this case, a strong emotional commitment and bond to the company has an important role in the improvement performance. High commitment of an employee will have an effect on performance employees. This is in accordance with the opinion of Meyer et al (1993) inPurbangkoro ( 2015) argued that those with high continuan commitment stayed because they felt they needed it, while employees who had high affective commitment stayed because they wanted it and normative commitment remained because they felt they should.

Research Husaini (2017) found that organizational commitment consisting of continuous commitment, affective commitment and normative commitment has an influence on the performance of the Nurse Pavilliun Cendana Hospital Dr. Moewardi Surakarta. Efliani's research (2015) also found that there was a significant effect of organizational commitment on the performance of nurses at the Regional General Hospital Dr. Moewardi Central Java.These findings support the results of research conducted by Wicaksana (2016) found that organizational commitment has a positive effect on the performance of nurses at the Yogyakarta Islamic Hospital.

\section{Conclusions and Suggestions}

\subsection{Conclusion}

Based on the research results above, the following conclusions can be formulated:

- Transformational leadership proven to have a positive and significant effect on organizational commitment. These results mean that the higher the transformational leadership, the higher the organizational commitment of employees at the Klungkung District Health Office.

- Career development has a positive and significant influence on organizational commitment. This result means that the better the career development of employees is able to strengthen their commitment in the organization at the Klungkung District Health Office

- Transformational leadership proven to have a positive and significant effect on organizational commitment. This result means that the stronger the understanding and implementation of transformational leadership, the stronger the performance of the Klungkung District Health Office employees.On the other hand, organizational commitment has not been able to mediate on the indirect effect transformational leadership on employee performance. Based on these results it can be stated, the organizational commitment obtained fromtransformational leadership have not been able to determine the performance of employees at the Klungkung District Health Office.

- Career development has a positive and significant influence on employee performance. These results mean that career development can improve the performance of employees at the Klungkung District Health Office, pthere is another side to korganizational commitment has not been able to mediate the indirect effect career development on employee performance. Based on these results it can be stated, the organizational commitment obtained fromgood career development have not been able to determine the performance of employees at the Klungkung District Health Office

- Organizational commitment has a positive and significant influence on nurse performance. This result means that the better employee commitment to the organization is able to improve employee performance at the Klungkung District Health Office

\subsection{Suggestion}

- The results showed that transformational leadership proven to have a positive and significant effect on organizational commitment, ke transformational leadership at the Klungkung District Health Office it is good measured by several indicators. However, the intellectual stimulation indicator gets the lowest average than other indicators. Methods that are done include providing enthusiasm for work, giving advice, motivating capacity development, approaching work rules and procedures as well as giving warnings and praise to organizational members to improve the performance of organizational members 
- The results showed that career development had a positive and significant impact on organizational commitment and career development at the Klungkung District Health Office it is good measured by several indicators. However, career planning indicators get the lowest average of other indicators. Efforts that can be done are:

- Prioritizing career development for employees who have completed higher education and have high performance in carrying out tasks

- Providing equal opportunities for employees to continue formal education to a higher level for career development

- Providing fair opportunities for employees to take part in trainings to improve employee work performance

- Providing fair opportunities for employees to learn in detail the new tasks that will be carried out by each employee

- Advise employees to consult with co-workers who are experienced about new tasks that will be carried out by employees

Other researchers can conduct qualitative research to examine more deeply about employee performance.

\section{References}

i. Ahmad. 2015. The Influence of Transformational Leadership and Organizational Culture on Job Satisfaction and Employee Performance of PT. Jamsostek (Persero) Surabaya Branch. Journal of Economics \& Management. Vol. 9 No. 1

ii. Ameliany. 2016. The Effect of Motivation and Career Development on Employee Performance with Job Satisfaction as an Intervening Variable for Employees of Panca Budi Medan. Master Thesis of Management Science, Faculty of Economics and Business, University of North Sumatra

iii. Armawati. 2017.The Effect of Career Development on the Organizational Commitment of PT. Panin Bank Pekanbaru Branch Office. MODUS Journal Vol. 25 (2)

iv. Asthu. 2016. The Effect of Job Satisfaction, Motivation, and Organizational Commitment on Nurse Performance at General Hospitals in Bandung City. Journal of Nursing Management Vol 18 Issue 1.

v. Badawi, Ahmad. 2017. Effect of Career Development, Compensation and Work Environment on Employee Performance of CV Sumber Baru Niaga. Thesis at Mercu Buana University, Jakarta

vi. Budi, T. Effect of Motivation, Career Development, and Job Satisfaction on Employee Performance with the Structural Equation Modeling Method. Journal of Industrial Engineering, Vol. 1, No.4, December 2013.

vii. Cahyono, Ujang. 2016. The Effect of Transformational Leadership on Employee Performance in Jember Plantation Companies. Journal of Management \& Agribusiness, Vol. 11 No. 2

viii. Country. 2014. The Influence of Career Development, Job Promotion, Job Characteristics and Achievement Motivation on Employee Performance at Kerinci District Health Office. Bung Hatta University Postgraduate Thesis

ix. Curtis and Wright. 2012. Retaining Employees - The Fast Track to Commitment. Management Research News, Vol. 24

x. Dewi, Nunik Lestari. 2018. The Influence of Transformational Leadership on the Performance of State-Owned Employees in Bandung City with Organizational Citizenship Behavior as a Moderation Variable (Study of PT. Kimia Farma (Persero) Tbk and PT. Bio Farma (Persero). Social Science Education Journal, 5 (1)

xi. Efliani. 2015. The Effect of Organizational Commitment on Nurse Performance in Regional General Hospital Dr. Moewardi Central Java. Journal of Management and Entrepreneurship, 7 (1)

xii. Fatimah. 2014. The Influence of Competence, Organizational Commitment and Job Satisfaction With Nurse Performance in Labuang Baji Hospital. Journal of Nursing Science Media. Volume 6 Issue 2

xiii. Gani. 2014. Staff and Organization Performance. Bandung: Faithful Library

xiv. Ghozali, Imam. 2014. Structural Equation Modeling, Alternative Methods with Partial Least Square (PLS) 4th Edition Semarang: Diponegoro University Publishing Agency.

xv. Gibson. 2013. Organization, behavior, structure, processes. Jakarta: Literacy Development

xvi. Griffin. 2012. Management. 7th edition. Massachusetts: Houghton Mifflin Company.

xvii. Hair, J., Hault, G., Ringle, C., \& Sarstedt, M. 2014. A Primer on Partial Least Squares Structural Equation Modeeling (PLS-SEM). SAGE Publications, Inc. California. USA

xviii. Handoko, T. Hani. 2013. Management, Issue 2. Yogyakarta: BPFE

xix. Hasibuan, Malayu SP 2012. Motivation in Improving Employee Performance. Third Edition. Jakarta: Earth Literacy

xx. Hero. 2014. Performance Evaluation of Human Resources. Jakarta: Four Salemba.

xxi. Husaini. 2017. The Influence of Organizational Commitment on the Nurse Performance of Dr. Pavilliun Cendana Hospital Dr. Moewardi Surakarta. Trikonomika Journal Volume 13, No. 2,

xxii. Ilyas. 2012. Performance: Theory, Assessment, Research. Depok: FKM UI

xxiii. Jose, Bobo. 2018. The Influence of Transformational Leadership, Motivation, and Job Satisfaction on Employee Performance, with Organizational Commitment as a Mediation Variable (Study at Pt. Intan Pariwara Klaten). Thesis of Master of Management Program, Faculty of Economics, University of Sanata Dharma

xxiv. Kesuma, I Gede Anggi Wira. 2018. The Effect of Transformational Leadership on Organizational Commitment by Mediating Organizational Citizenship Behavior and Job Satisfaction. Management E-Journal of Udayana University, 5 (6) 
xxv. Klungkung District Health Office. 2018. Results of Evaluation and Monitoring of Minimum Service Standards. Klungkung: Data and Reporting Section

xxvi. Live. 2015. The Effect of Job Satisfaction on Organizational Commitment and Employee Performance and Study Service Performance at Public Health Center Health Services in East Kalimantan. Journal of Management Volume 4 Issue 1

xxvii. Luthfan. 2014. Organizational Behavior. Issue Ten, PT. Andi: Yogyakarta

xxviii. Manggis, I. W., Yuesti, A., \& Sapta, I. K. S. (2018). The Effect of Career Development and Organizational Culture to Employee Performance with Motivation of Work as Intervening Variable in Cooperation in Denpasar Village. International Journal of Contemporary Research and Review, 9(07), 20901-20916.

xxix. Mangkunegara. 2014. Company Human Resource Management. Bandung: PT Remaja Rosdakarya

xxx. Margono. 2010. Educational Research Methodology. Jakarta: Rineka Cipta.

xxxi. Marsoit. 2017. The Influence of Training, Work Discipline and Organizational Commitment on Employee Performance of PT. Insurance Services Indonesia. Journal of EMBA Vol. 5 No.3 September 2017

xxxii. Ministry of Health RI. 2008. Decree of the Minister of Health of the Republic of Indonesia number: 741 / MENKES / PER / VII / 2008 concerning Minimum Service Standards in the Health Sector in Regencies / Cities. Jakarta: Ministry of Health.

xxxiii. Mutamimah. 2013. Globalization and Transformational Leadership. ECOBIS, Vol. 2, No. 1: 1 - 8

xxxiv. Nawawi. 2014. Organizational Behavior. Book 1. Jakarta: Four Salemba.

xxxv. Nikpour. 2017. A Multidimensional Analysis of Ethical Climate, Job Satisfaction, Organizational Commitment, And Organizational Citizenship Behavior. Asia University

xxxvi. O'Leary, Elizabeth. 2012. Leadership. First Edition. Andi Yogyakarta.

xxxvii. Panggabean. 2012. Managing Human Resources: Performance, Motivation, Job Satisfaction and Productivity. Yogyakarta: Oriza

xxxviii. Perdana and Andriyani, 2019. The Influence of Work Motivation, Leadership and Career Development Opportunities on Employee Performance at PT. Nyonya Meneer Semarang. Journal of Economics. Vol. 21 No. 2.

xxxix. Prihansa, DJ 2016. Planning and Human Resource Development. Bandung: Alfabeta

xl. Ramli. 2017. The Effect of Career Development on the Performance of Inpatient Nurses at H. Hanafie Muara Bungo Hospital, Jambi. Journal of Management Applications Volume 01, No. 01

xli. Ratanto. 2015. Career Development as the Most Influencing Factor of Implementing Nurse Performance. Indonesian Nursing Journal, Volume 16 No.2, July 2015.

xlii. Rivai and Sagala. 2014. Human Resource Management for Companies from Theory to Practice. Jakarta: PT Raja Grafindo

xliii. Robbins. 2015. Organizational Behavior. Tenth Edition. Jakarta: PT. Gramedia Group Index

xliv. Robina. 2015. Analysis of the Effect of Organizational Commitment on Performance with Work Discipline as an Intervening Variable. Journal of Management Volume 4 Issue 1

xlv. Rosmadi. 2017. The Influence Of Career Development And Work Environment On The Performance Of Study Employees At PT. Taspen Persero Manado Branch. Journal of Management Applications Volume 01, No. 01

xlvi. Sedarmayanti. 2015. Human Resources and Work Productivity. Bandung: CV Mandar Maju.

xlvii. Septiani. 2014. The Effect of Organizational Commitment on Work Discipline of Civil Servants at Regional Civil Service Bodies in Cimahi City. Journalist E-Journal, Volume I Number 2

xlviii. Septyan, F. 2016. The Effect of Transformational Leadership Style on Motivation and Performance (Study on Employees of CV. Jade Indopratama Malang). Journal of Business Administration (JAB) Vol. 53 No. December 1, 2017

xlix. Siagian, SP 2014. Human Resource Management Edition 1 Printing 19. Jakarta: PT. Bima Aksara.

l. Simamora. 2014. Human Resources, Yogyakarta: STIE YKPN.

li. Son. 2014. The Influence of Organizational Culture, Compensation and Career Development on Nurses' Job Satisfaction and Its Impact on Nurse Performance in Regional Public Service Bodies of Aceh Mental Hospital. Journal of Nursing Management Vol.10 Issue 2.

lii. Sugiyono. 2014. Educational Research Methods. Bandung: CV Alfabeta

liii. Suhana. 2017. Relationship Analysis of Transformation Leadership Style, Commitment and Performance of employees (Study in People Crediting Bank (BPR) in Central Java), Usahawan No. 10, TH XXXVI, p. 47-53

liv. Suklentiana. 2015. The Influence of Work Culture and Employee Commitment on Employee Performance (Study on the Service and Licensing Agency of Bandung City. Jurnal Valuta Vol. 3 No 1, April 2015

lv. Sularso, Bambang. 2015. The Effect of Organizational Commitment and Work Discipline on Employee Performance and Its Implications on Career Satisfaction (Empirical Study in West Semarang District). Journal of Currency Vol. 3 No 1, April 2015

lvi. Sutrisno. 2014. The Effect of Job Stress on Employee Performance in Madrasah 4Aliyah Negeri Demak. Catalogist E-Journal. Vol. 1 No. 1

lvii. Tanuwibowo. 2017. The Effect of Commitment on Employee Performance at PT Tirta Sarana Sukses. Journal of Applied Science No. 1 Vol. 1

lviii. Vipraprastha, T., Sudja, I. N., \& Yuesti, A. (2018). The Effect of Transformational Leadership and Organizational Commitment to Employee Performance with Citizenship Organization (OCB) Behavior as Intervening Variables (At PT Sarana Arga Gemeh Amerta in Denpasar City). International Journal of Contemporary Research and Review, 9(02), 20503-20518. 
lix. Wake up. 2012. Human Resource Management. Jakarta: Erlangga

lx. Wicaksana. 2016. Influence Organizational Commitment to Nurse Performance in Yogyakarta Islamic Hospital. Journal of Business \& Economics, 19 (2).

lxi. Winardi. 2015. Motivation Grado in Management. Jakarta: PT. Raja Grafmdo Persada, Jakarta

lxii. Yatnikasari. 2010. The Relationship between the Retention Program and the Organizational Commitment of Implementing Nurses at RSAB Harapan Kita. Thesis. University of Indonesia

lxiii. Zurnali. 2014. Learning Organization, Competency, Organizational Commitment, and Customer Orientation: Knowledge Worker-Research Framework for Human Resource Management in the Future ". Bandung: Unpad Press 